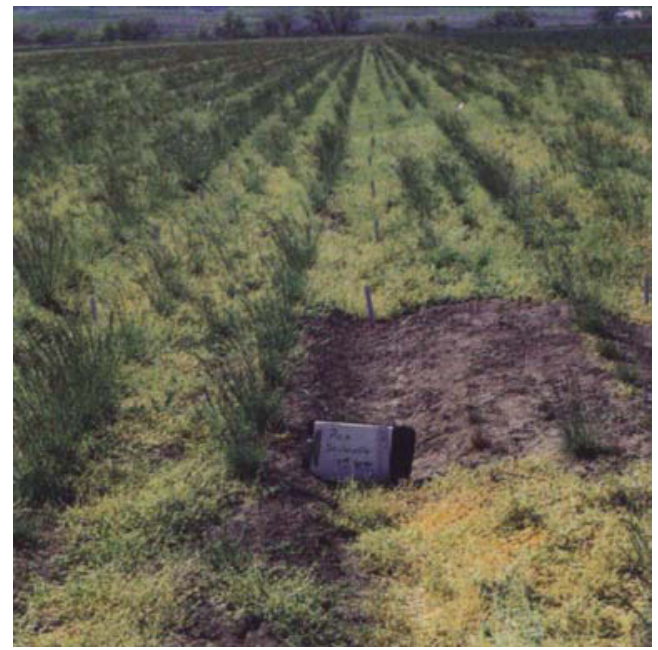

One-sided bluegrass Winters plots show dense common chickweed growth except where chlorsulfuron plus orazylin was used.

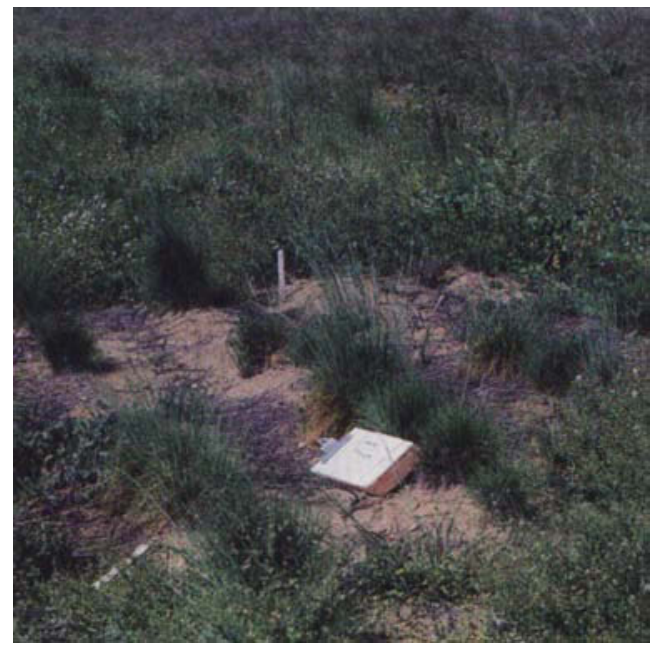

Chlorsulfuron provided good control of weeds in 2-year-old Idaho fescue, without affecting grass vigor.

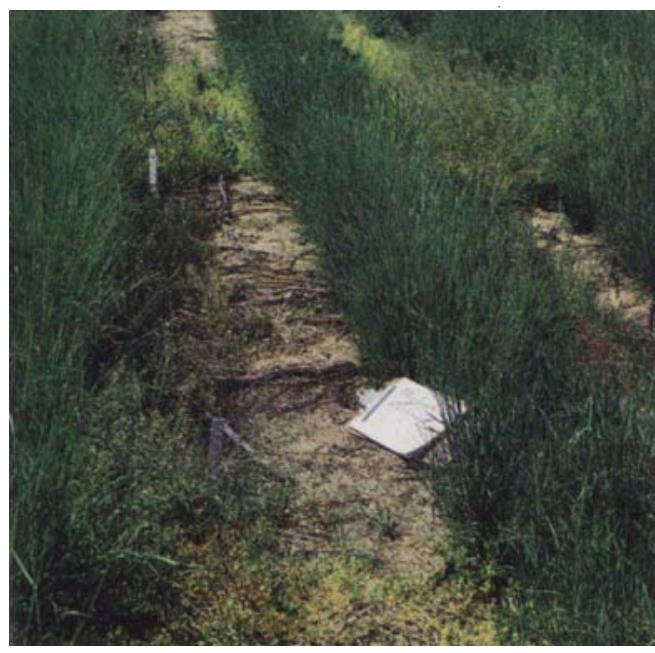

Older grasses, such as this 2-year-old California melic, were often not affected by herbicide treatment.

\title{
Preemergence herbicides have little effect on vigor of perennial grasses
}

\author{
W. Thomas Lanini $\square$ Rachael F. Long $\square \quad$ John Anderson
}

\section{Perennial grass stands often face stiff competition from weeds, par- ticularly during the first few years after grass establishment. Field studies were conducted to evalu- ate the tolerance of several estab- lished perennial grasses to pre- emergence herbicides in order to selectively suppress weeds. Grass vigor was reduced by some herbicides, but most had minimal effects. The herbicides that con- trolled weeds best also caused the greatest reduction in grass vigor.}

Before the sweeping alteration of California's landscape by European introduction of livestock, agricultural crops and invasive weeds, perennial bunchgrasses dominated much of California and other western states. The introduction of livestock, combined with drought, led to overgrazing of many areas. The massive influx of settlers in the 1800 s increased the land under cultivation and also led to the introduction of many alien species. The result is that the native flora has been almost entirely replaced by introduced annual and perennial weedy plant species; California grasslands today are mostly composed of introduced annual species. This shift in the native grass community has resulted in a degradation of rangelands, increased problems with soil erosion and weed control, enhanced fire danger and loss of wildlife habitat.

To address these concerns there have been attempts to propagate native perennial grasses in California landscapes, including parks and recreation areas, agricultural and urban areas, and along right-of-ways. Current methods of establishing perennial grass stands include broadcast seed- ing, drilling and transplanting. Competition from annual weeds has caused many new plantings to fail, discouraging some people and agencies from using native perennial grasses in revegetation programs. $\mathrm{Al}$ though many factors affect stand persistence, such as adaptability of the species to the site, competition from invasive annual grass and broadleaf weeds remains the most troublesome and difficult to manage.

Weed management during early development of the perennial grass stand is critical to successful establishment. Once native grass stands achieve full coverage of a site and are properly managed, they are able to compete for light, nutrients and water and to retard weed invasion. Some weed control measures may be necessary in established perennial grasses where large weed seed banks exist or where grass stands are sparse. Management tools available to control weeds in perennial grass stands include tillage, hoeing, mowing, grazing and use of fire and herbicides. The cultural methods by themselves suppress weeds in most cases, but tend to be costly and time consuming, and may not be feasible or appropriate in some situations, such as on hilly land or near urban areas. Chemical weed management is often a faster and cheaper means of weed control.

Several postemergence broadleaf herbicides can control broadleaf weeds in perennial grasses. Preemergence herbicides, including picloram and atrazine, control annual weeds with low phytotoxicity to perennial grasses. Picloram is not labeled for use in California, and atrazine use has been restricted due to its detection in wells.

Information on tolerance of California native perennial grass species to 
preemergence herbicides and the appropriate use rates for California conditions is limited. Therefore work on nonnative perennial grasses was examined for possible leads on candidate herbicides. Two perennial grasses, Kentucky bluegrass (Poa pratensis) and tall fescue (Festuca arundinacea), were found to be relatively tolerant of chlorsulfuron at rates less than 0.70 ounces per acre $(\mathrm{oz} / \mathrm{ac})$, but at rates up to $4 \mathrm{oz} /$ ac tall fescue growth was reduced by $30 \%$. Six species of container-grown ornamental grasses were found to be tolerant of oxidiazon at 2 pounds per acre (lb/ac), and four of the six species were tolerant to oryzalin at $2 \mathrm{lb} /$ ac. Several preemergence herbicides were identified in preliminary studies as having potential to control annual weeds without significant injury to established perennial grasses.

The objective of this study was to evaluate weed control in and tolerance of six California native perennial grass species to selected preemergence herbicides.

\section{Trials at Rio Vista and Winters}

We set up field trials on Sept. 23 , 1992 and Nov. 17, 1993 on established California native grasses: meadow barley (Hordeum brachyantherum Nevski); blue wildrye (Elymus glaucus Buckley); California melic (Melica californica Scribner); Idaho fescue (Festuca idahoensis Elmer); nodding needlegrass [Nassella cernua (Stebb. \& Love) Barkworth]; and one-sided bluegrass (Poa secunda spp. secunda J.S. Presl.). The 1992 trials were located near Rio Vista (25 miles south of Sacramento) in a soil with $3.3 \%$ organic matter, $11 \%$ sand, $43 \%$ silt and $46 \%$ clay. The 1993 trials were located near Winters (30 miles west of Sacramento) in a soil with $1.2 \%$ organic matter, $17 \%$ sand, $45 \%$ silt and $38 \%$ clay. Grasses had been planted as monocultures one or more years prior to the initiation of this study; thus each grass species represented a separate trial. In 1992 one location was used for each species; in 1993 two locations were used for Idaho fescue, California melic, meadow barley and one-sided bluegrass, and one for the other species.
We arranged the experiments in a randomized complete block with three replications, with each plot measuring 10 feet by 20 feet.

At both locations and in both years, seasonal native grass growth had just started at the time of herbicide application. The herbicides evaluated in these studies were all preemergence herbicides, requiring rainfall or irrigation for activation (table 1). We observed excessive native grass injury in the 1992 studies when chlorsulfuron or oryzalin was used and therefore reduced application rates for these in the 1993 studies. Herbicides were applied using a $\mathrm{CO}_{2}$-powered backpack sprayer, using 8002 nozzles at $30 \mathrm{PSI}$; spray volume was 25 gallons per acre. At the Rio Vista site, plots were sprinkler-irrigated with 0.75 inches of water following treatment to incorporate the herbicides. The Winters site lacked irrigation so we timed applications to coincide with the start of seasonal rainfall. Rainfall from the time of herbicide application to the time of vigor evaluation was 17.45 inches at Rio Vista and 6.68 inches at Winters.

Weed control and grass vigor were evaluated on March 15, 1993 and March 31, 1994. The principal weeds at both sites were winter annuals. Weed species were combined, and percent weed control was visually assessed, noting the weed species that were not controlled. Grass vigor - a visual ranking of grass height, tillering and color - was evaluated in each plot. A vigor ranking of 5 represented healthy, robust grass with excellent color. A value of 1 represented grass with no new growth or tillering but still alive. A value of 0 represented dead grass. Values less than 5 were estimates of percent growth and color reduction. Grass height was measured at the Winters location. Height measurements were made on four random individuals in each plot and averaged to give mean grass height for each treatment.

\section{Weed control and grass vigor}

As shown in table 2, grass vigor varied by species, age of stand at treatment time, herbicide and weed pressure on the study site. Grass vigor rat- ings on untreated plots was often less than 5 due to the competition from weeds reducing growth.

Idaho fescue. At both study sites, 1-year-old Idaho fescue was less vigorous when oryzalin or the combination of chlorsulfuron and oryzalin was used (table 2). The Idaho fescue vigor on oryzalin-treated plots at Winters was reduced in spite of less rainfall and a reduction in the rate of the herbicide. Additionally, at Winters, chlorsulfuron treatment reduced the vigor of Idaho fescue. The reduction in vigor from chlorsulfuron treatment corresponded closely with observations made in other studies. In 2-yearold Idaho fescue plantings, no difference in vigor was observed among treatments. Height measurements of 1-year-old Idaho fescue indicated that treatment with either chlorsulfuron or oryzalin caused significant height reductions (table 3). Height of 2-year-old Idaho fescue was not affected by herbicide treatment.

At Rio Vista, weed control was improved by the herbicide treatments with the exception of the simazine treatment (table 4). Simazine at the $1 \mathrm{lb} /$ ac rate was not effective in controlling broadleaf weeds. At Winters, in 1-year-old Idaho fescue, the major weeds were chickweed (Stellaria media) and annual sowthistle (Sonchus oleraceus). Treating with chlorsulfuron or the combination of chlorsulfuron and oryzalin resulted in complete weed control for the duration of the winter growing season, while other treatments were less effective. In 2-year-old Idaho fescue, chlorsulfuron, the combination of chlorsulfuron and oryzalin, simazine and oxadiazon all provided good weed control. Oryzalin at the $0.75 \mathrm{lb} / \mathrm{ac}$ rate and diuron both failed to control the common groundsel (Senecio vulgaris) and little mallow

\begin{tabular}{|c|c|c|}
\hline \multicolumn{3}{|c|}{$\begin{array}{l}\text { TABLE 1. Preemergence herbicides and } \\
\text { application rates evaluated for each study site }\end{array}$} \\
\hline Herbicide & io Vista, 1992 & Winters, 1993 \\
\hline & \multicolumn{2}{|c|}{ 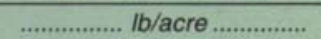 } \\
\hline Chlorsulfuron & 0.06 & 0.05 \\
\hline Chlorsulfuron + oryzalin & $0.03+1.0$ & $0.03+0.5$ \\
\hline Oryzalin & 2.0 & 0.75 \\
\hline Diuron & 2.0 & 2.0 \\
\hline Oxadiazon & 2.0 & 2.0 \\
\hline Simazine & 1.0 & 1.0 \\
\hline Untreated & & \\
\hline
\end{tabular}




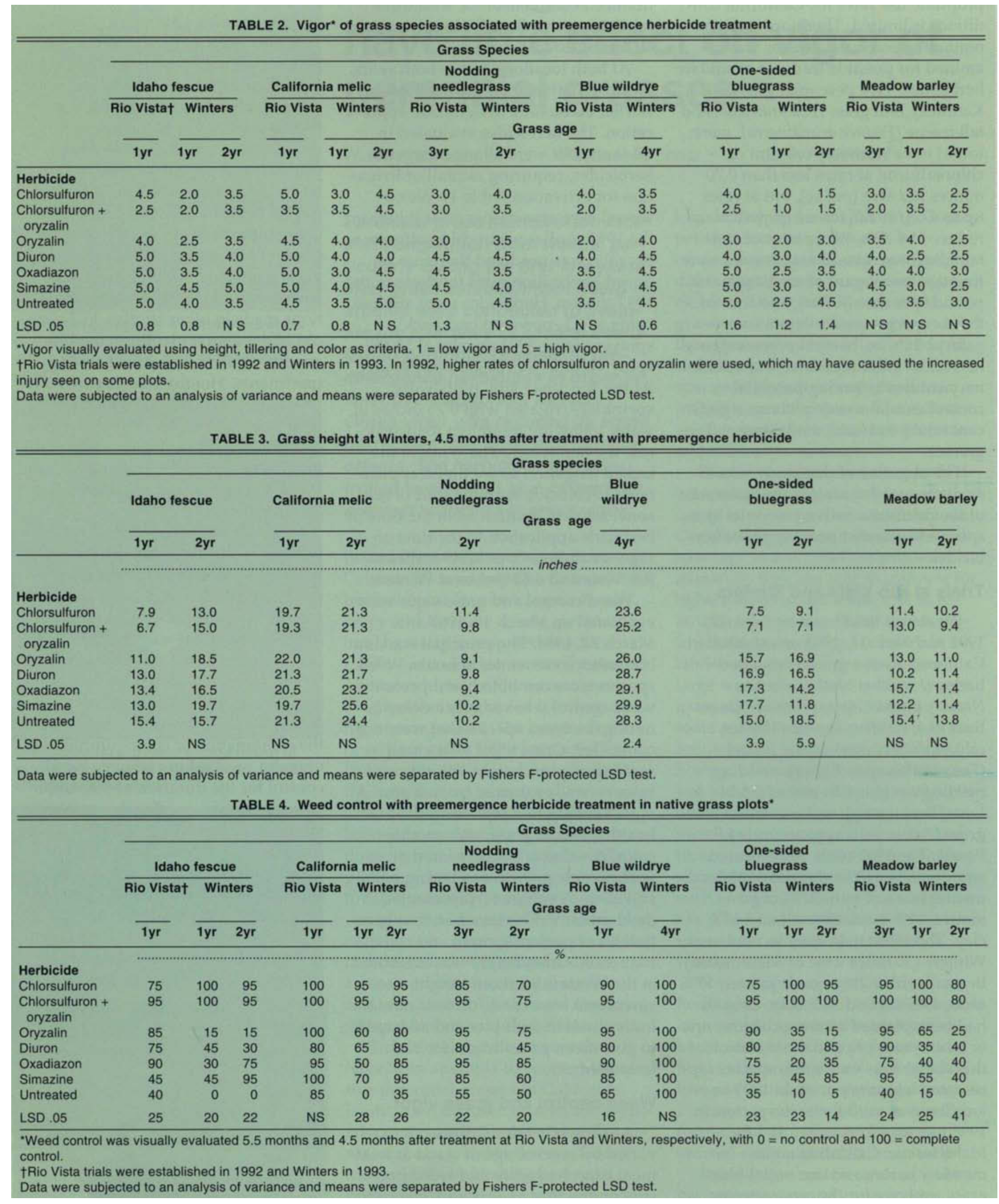


(Malva parviflora) that were common at this location.

California melic. One-year-old grass vigor was reduced more in Winters than in Rio Vista (table 2).

Chlorsulfuron plus oryzalin in Rio Vista was the only treatment with a vigor rating significantly lower than untreated grass. In 2-year-old California melic, vigor was not significantly different among treatments. Two-yearold California melic had higher vigor ratings than 1-year-old grasses at Winters. The larger 2-year-old grasses may have been more competitive with the weeds that were present, improving weed control (table 4). Also, a deeper root system in the older grass may have reduced the exposure to the preemergence herbicides. Weed control on the 1-year-old California melic did not vary among treatments at Rio Vista, but was generally higher for the treatments that included chlorsulfuron at Winters (table 4). All herbicide treatments were significantly better at increasing weed control in contrast with the untreated in 2-year-old California melic. Although the principal weeds at Winters in California melic plots were similar to those in the Idaho fescue plots, weed control was greater on the California melic sites and is probably related to the greater height and vigor of California melic (tables 2 and 3 ).

Nodding needlegrass. Vigor of 3year-old nodding needlegrass was reduced by oryzalin at $2 \mathrm{lb} / \mathrm{ac}$ rate and by chlorsulfuron (table 2). Neither vigor nor height of 2-year-old nodding needlegrass was significantly affected by treatment, although some trend toward less vigor was noted in the oryzalin-treated grass. The higher treatment rates for chlorsulfuron and oryzalin used in 1992 on the 3-year-old grass may have accounted for the observed reduction in vigor. All herbicide treatments significantly improved weed control in 3-year-old nodding needlegrass (table 4). Herbicide treatments were generally less effective at increasing weed control in 2-year-old nodding needlegrass compared to 3year-old grass. The principal escape weed in the 2-year-old nodding needlegrass was field bindweed (Convolvulus arvensis), with only chlorsulfuron, oryzalin and oxadiazon providing weed control greater than observed on untreated plots.

Blue wildrye. Both chlorsulfuron and chlorsulfuron plus oryzalin reduced vigor of 4-year-old blue wildrye plants (table 2), while 1-year-old blue wildrye was not significantly affected by treatment. One-year-old blue wildrye treated with oryzalin had the lowest vigor ratings. Weed control was significantly improved by all herbicide treatments in 1-year-old blue wildrye (table 4). No difference in weed control was seen in the 4-yearold blue wildrye, as weed pressure was very low on this site. This site had been burned approximately 1 month prior to establishing the trial, and very few annual weeds survived the fire or emerged after the burn. This may also have predisposed blue wildrye to herbicide injury.

One-sided bluegrass. One-sided bluegrass vigor was significantly reduced by oryzalin and by oryzalin plus chlorsulfuron treatments (table 2). Reducing the rate of oryzalin or chlorsulfuron in 1993 did not improve the vigor rating in one-sided bluegrass. The Winters site had a dense common chickweed population, which reduced vigor in all plots compared to Rio Vista.

Simazine reduced the vigor of 2year-old one-sided bluegrass, which was unexpected since previous work has shown reduced vigor of several native perennial grass species when simazine was used at $2 \mathrm{lb} / \mathrm{ac}$, but little or no injury at the $1 \mathrm{lb} / \mathrm{ac}$ rate. The 2year-old one-sided bluegrass was located a short distance from the other grass species and had different soil characteristics. The soil had less organic matter $(0.85 \%)$ and more sand $(36 \%)$ than at the other locations.

Treatments that reduced vigor of onesided bluegrass also reduced height (table 3). The most dramatic effects were from chlorsulfuron, where height growth was reduced by $50 \%$. Improvements in weed control were greatest in plots where grass vigor reduction was also greatest (tables 2 and 4). Chlor- sulfuron provided almost complete control of the principal weeds at Winters, common chickweed and little mallow.

Meadow barley. Vigor of meadow barley did not differ among treatments for any of the age groups evaluated (table 2). Poor common chickweed control was observed at Winters on all plots not using chlorsulfuron or chlorsulfuron plus oryzalin (table 4). Two-year-old meadow barley plants generally were less vigorous than 1year-old plants at Winters. Weed pressure was much greater in the 2-yearold grass plots than in the 1-year-old plots. The decreased weed control on the 2-year-old plots resulted in more competition and less grass vigor.

Three-year-old meadow barley generally displayed increased vigor compared to younger grasses, particularly when oxadiazon, diuron or simazine was used (table 2). In 1992 higher rates of chlorsulfuron and oryzalin were used, which may have caused the increased injury seen on these plots.

\section{Conclusion}

Vigor of established perennial bunchgrasses was affected by herbicide treatment. Vigor was also generally reduced by dense weed cover. The treatments that consistently controlled the winter annual weeds in these trials were chlorsulfuron and the combination of chlorsulfuron and oryzalin. However, these treatments generally caused some reduction in grass vigor. Rates of chlorsulfuron and oryzalin were both reduced after the first year of study in an attempt to reduce grass injury, with only limited improvement observed after rates were reduced. Since weed control is still very good at the reduced rates, particularly with chlorsulfuron, further rate reduction may be possible without reducing weed control and could reduce grass injury.

W.T. Lanini is Extension Weed Ecologist, Department of Vegetable Crops, UC Davis; R.F. Long is UC Cooperative Extension Farm Advisor, Solano and Yolo counties; and J. Anderson is Consultant, Hedgerow Farms, Winters. 